\title{
EKSTRAKSI PEKTIN DARI KULIT BUAH PISANG RAJA (Musa sapientum)
}

\author{
Farida Hanum, Irza Menka Deviliany Kaban, Martha Angelina Tarigan \\ Departemen Teknik Kimia, Fakultas Teknik, Universitas Sumatera Utara, \\ Jl. Almamater Kampus USU Medan 20155, Indonesia \\ Email: ida_hanum78@yahoo.co.id
}

\begin{abstract}
Abstrak
Pektin secara luas digunakan dalam pengolahan makanan khususnya untuk mengubah buah-buahan yg memiliki nilai yang rendah menjadi produk-produk berkualitas baik seperti selai, jelly, dan permen. Pektin juga memiliki banyak aplikasi dalam produk makanan dan obat-obatan sebagai agen pembentuk gel dan agen penstabil. Penelitian ini bertujuan untuk memanfaatkan limbah kulit buah pisang raja (Musa Sapientum) sebagai sumber pektin. Penelitian ini dilakukan dengan metode ekstraksi menggunakan pelarut asam klorida $(\mathrm{HCl})$ kemudian ditambahkan etanol ke dalam filtrat untuk mengendapkan pektin dan proses terakhir dilakukan pengeringan untuk mendapatkan pektin kering. Variabel tetap yang digunakan dalam penelitian ini adalah berat kulit pisang raja (Musa Sapientum) 10 gram, kadar air awal bahan 10\%, dan pelarut asam klorida $(\mathrm{HCl})$. Sedangkan variabel berubahnya adalah pH ekstraksi 1; 1,5; 2; waktu ekstraksi 70, 80, 90, 100 menit, dan temperatur ekstraksi $80^{\circ} \mathrm{C}, 90$ ${ }^{\circ} \mathrm{C}$. Hasil penelitian menunjukkan bahwa rendemen hasil ekstraksi terbaik dapat diperoleh pada temperatur $90^{\circ} \mathrm{C}, \mathrm{pH} 1,5$ sebesar 59\% selama 80 menit dengan kadar air 11,93\%, kadar abu 0,79\%, berat ekivalen 600-800mg dan kadar metoksil 4,43\%.
\end{abstract}

Kata kunci : berat ekivalen, ekstraksi, kadar metoksil pektin, rendemen

\begin{abstract}
Pectin is extensively utilized by the food processors especially for conversion of low grade fruits in to good quality products like jam, jelly, marmalade, and candies. Pectin has many applications in food and pharmaceuticals products as gelling agents and stabilizers. This research aims to utilize banana peel waste (Musa sapientum) as a source of pectin. The research used a solvent extraction method using hydrochloric acid $(\mathrm{HCl})$ in additional to ethanol to precipitate the pectin and the last step drying process to obtain dry pectin. The fixed variables which were used in this research were 10 grams of banana peel (Musa sapientum), $10 \%$ water content of sample, and hydrochloric acid (HCl) as a solvent. The extraction process was carried out by $\mathrm{pH} 1$; 1.5, 2; the time of 70, 80, 90, 100 minutes, and the temperature of $80^{\circ} \mathrm{C}, 90^{\circ} \mathrm{C}$. The results showed that the highest yield of the extraction was obtained at $90^{\circ} \mathrm{C}, \mathrm{pH} 1.5$ during 80 minutes with $11.93 \%$ water content of $0.79 \%$ ash content, about 600-800mg and 4, 43\% methoxyl content.
\end{abstract}

Keywords : equivalent weight, extraction, methoxyl content, pectin, yield

\section{Pendahuluan}

Di Indonesia, komoditas pisang menduduki tempat pertama di antara jenis buah buahan lainnya, baik dari segi luas pertanamannya maupun dari segi produksinya. Total produksi pisang di Indonesia pada tahun 2006 berkisar antara 5.037.472 ton.

Berdasarkan data terakhir yang diperoleh, saat ini luas lahan yang ditanami pisang di daerah Sumatera Utara berkisar 3.195,60 hektar dengan produktivitas 5,32 kuintal per hektar. Setiap tahunnya daerah tersebut bisa menghasilkan 160.888 ton buah pisang, termasuk di dalamnya buah pisang raja (Musa Sapientum) [13].Bobot kulit pisang mencapai 40\% dari buahnya [4]. Dengan demikian kulit pisang menghasilkan limbah dengan volume yang besar [9].
Pektin adalah suatu komponen serat yang terdapatpada lapisan lamella tengah dan dinding sel primer pada tanaman [13]. Sedangkan menurut Hoejgaard pektin merupakan asam poligalakturonat yang mengandung metil ester [20].

Pektin merupakan pangan fungsional bernilai tinggi yang berguna secara luas dalam pembentukan gel dan bahan penstabil pada sari buah, bahan pembuatan jelly, jam dan marmalade [20]. Konsentrasi pektin berpengaruh terhadap pembentukan gel dengan tingkat kekenyalan dan kekuatan tertentu [12].

Pektin secara luas berguna sebagai bahan tekstur dan pengental dalam makanan [3], mampu membungkus logam berat [17] dan juga sebagai bahan tambahan produk susu terfermentasi [16]. Selain itu menurut Yamada rantai sisi pektin yang komplek 
mempunyai aktivitas anti kanker dan senyawa bioaktif lainnya [7]. Kondisi ekstraksi pektin berpengaruh terhadap karakteristik pektin [8] dan sifat fisik pektin tergantung dari karakteristik kimia pektin [2]. Suhu yang tinggi selama ekstraksi dapat meningkatkan rendemen pektin. Suhu yang agak tinggi. Buah pisang mengandung pektin dalam konsentrasi tinggi.

Buah pisang mengandung pektin dalam konsentrasi tinggi. Kandungan pektin pada kulit pisang berkisar antara $0,9 \%$ dari berat kering. Pektin tersebut dapat diekstraksi dengan cara sederhana, biaya yang tidak mahal dan dapat diterapkan dalam skala kecil [7].

Hingga tahun 2011, seluruh pektin yang digunakan di industri-industri Indonesia adalah barang impor. Jumlah impor pektin cukup besar, yaitu lebih besar dari 100 ton per tahun dan harganya sangat mahal, membuat biaya impor pektin berdampak terhadap pengurangan devisa negara yang besar pula [2].

\section{Teori}

Pektin merupakan polimer dari asam Dgalakturonat yang dihubungkan oleh ikatan $\beta-1,4$ glikosidik. Asam D-galakturonat memiliki struktur yang sama seperti struktur D-galaktosa, perbedaannya terletak pada gugus alkohol primer C6 yang memiliki gugus karboksilat [6] seperti yang terlihat pada gambar 1.

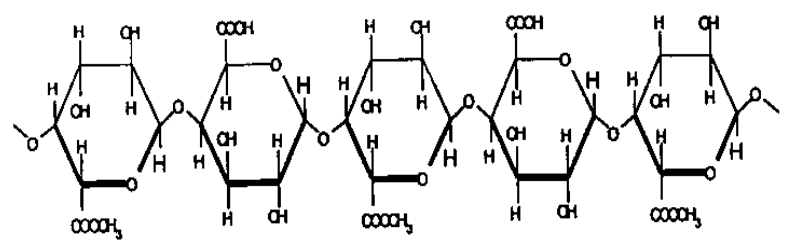

\section{Gambar 1. Senyawa Asam Pektinat atau Pektin}

Penggunaan asam dalam ekstraksi pektin adalah untuk menghidrolisis protopektin menjadi pektin yang larut dalam air ataupun membebaskan pektin dari ikatan dengan senyawa lain, misalnya selulosa. Meyer menyatakan bahwa protopektin menjadi pektin merupakan makromolekul yang merupakan berat moleku tinggi, terbentuk antara rantai molekul pektin satu sama lai atau dengan polimer lain.

Protopektin tidak larut karena dalam bentuk garam kalsium-magneium pektinat. Proses pelarutan protopektin menjadi pektin terjadi karena adanya penggantian ion kalsium dan magnesium oleh ion hidrogen ataupun karena putusnya ikatan antara pektin dan selulosa. Semakin tinggi konsentrasi ion hidrogen (pH) makin rendah kemampuan menggantikan ion kalsium dan magnesium ataupun memutus ikatan dengan selulosa akan semakin tinggi pula dan pektin yang larut akan bertambah [14].
Perubahan-perubahan senyawa pektin di dalam buah-buahan dan interelasinya dapat dilihat pada gambar 2 .

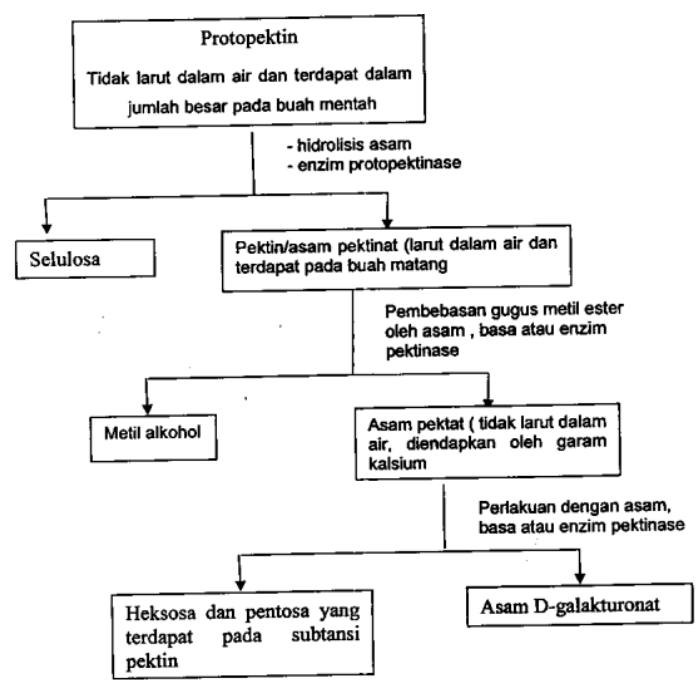

Gambar 2. Perubahan senyawa-senyawa pektin di dalam buah-buahan dan interelasinya [11]

\section{Metodologi Penelitian}

Bahan baku yang digunakan dalam penelitian ini adalah kulit buah pisang raja (Musa Sapientum) dan bahan kimia berupa asam klorida $(\mathrm{HCl})$, air $\left(\mathrm{H}_{2} \mathrm{O}\right)$, etanol $\left(\mathrm{C}_{2} \mathrm{H}_{5} \mathrm{OH}\right)$, perak nitrat $\left(\mathrm{AgNO}_{3}\right)$, natrium hidroksida $(\mathrm{NaOH})$, natrium klorida $(\mathrm{NaCl})$, dan phenolptalein. Tahap awal adalah persiapan bahan baku dimana kulit buah pisang raja dikeringkan di oven dan diukur kadar airnya $10 \%$.

Percobaan utama untuk mengetahui pengaruh temperatur, $\mathrm{pH}$, dan waktu ekstraksi terhadap rendemen, kadar air, kadar abu, dan kadar metoksil. Percobaan dilakukan dengan variasi temperatur 80 ${ }^{\circ} \mathrm{C}$ dan $90{ }^{\circ} \mathrm{C}$, variasi $\mathrm{pH} 1 ; 1,5 ; 2$ dan variasi waktu ekstraksi 70, 80, 90, dan 100 menit. Rangkaian alat yang digunakan seperti gambar 2 . 


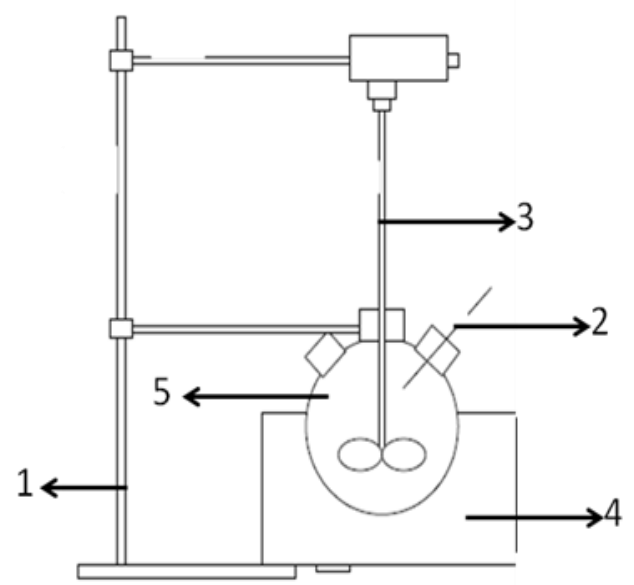

Gambar 3. Rangkaian peralatan ekstraksi

Keterangan :

1. Statif dan klem

2. Termometer

3. Stirrer

4. Heating mantle

5. Labu leher tiga

Kemudian dilakukan tahap filtrasi untuk memisahkan filtrat dari ampasnya. Filtrat didinginkan kemudian dilakukan pengendapan pektin dengan menambahkan etanol yang telah diasamkan. Endapan pektin yang diperoleh kemudian dikeringkan dalam oven pada temperatur $40^{\circ} \mathrm{C}$ selama 8 jam. Pektin kering dianalisa kadar air, kadar abu, berat ekivalen, dan kadar metoksilnya. Kemudian hasil analisa dibandingkan dengan standar mutu pektin berdasarkan standar mutu International Pectin Producers Association (IPPA) pada tabel 1 .

Tabel 1. Standar Mutu Pektin Berdasarkan Standar Mutu International Pectin Producers Association [9]

\begin{tabular}{|l|l|}
\hline \multicolumn{1}{|c|}{ Faktor Mutu } & \multicolumn{1}{c|}{ Kandungan } \\
\hline Kekuatan gel & Min 150 grade \\
Kandungan metoksil : & $>7,12 \%$ \\
- Pektin metoksil tinggi & $2,5-7,12 \%$ \\
- Pektin bermetoksil rendah & Min 35\% \\
Kadar asam galakturonat & Maks $12 \%$ \\
Susut pengeringan (kadar air) & Maks $10 \%$ \\
Kadar abu & Maks $12 \%$ \\
Kadar air & \\
Derajat esterifikasi untuk : & Min $50 \%$ \\
- Pektin ester tinggi & Maks 50\% \\
- Pektin ester rendah & $0,15-0,45 \%$ \\
Bilangan Asetil & $600-800 \mathrm{mg}$ \\
Berat Ekivalen & \\
\hline
\end{tabular}

Hasil
Data hasil percobaan rendemen pektin yang diperoleh setelah proses ekstraksi dapat dilihat pada tabel 2.

A. Pengaruh $\mathrm{pH}$ dan waktu ekstraksi terhadap rendemen pektin

Gambar 4 menunjukkan bahwa temperatur, $\mathrm{pH}$, dan waktu ekstraksi berpengaruh terhadap rendemen pektin hasil ekstraksi. Pada waktu hidrolisis yang singkat, protopektin baru sedikit terhidrolisis sehingga rendemen yang dihasilkan juga masih sedikit. Namun, apabila suhu dan waktu ekstraksi terlalu tinggi akan menyebabkan perusakan terhadap pektin [19].

Oleh karena itu, pada penelitian ini diperoleh rendemen yang terbaik pada waktu ekstraksi 80 menit pada suhu $90{ }^{\circ} \mathrm{C}$ dan $\mathrm{pH} 1,5$ yaitu $59 \%$.

\section{Tabel 2. Data hasil rendemen}

\begin{tabular}{|c|c|c|c|c|}
\hline $\mathrm{pH}$ & $\begin{array}{c}\text { Suhu } \\
\left({ }^{\circ} \mathrm{C}\right)\end{array}$ & $\begin{array}{l}\text { Waktu } \\
\text { (menit) }\end{array}$ & $\begin{array}{l}\text { Massa } \\
\text { Pektin } \\
\text { (gram) }\end{array}$ & $\begin{array}{c}\text { Kadar Metoksil } \\
(\%)\end{array}$ \\
\hline \multirow{8}{*}{1} & \multirow{4}{*}{80} & 70 & 2,5 & 2,33 \\
\hline & & 80 & 5,1 & 2,48 \\
\hline & & 90 & 5 & 2,67 \\
\hline & & 100 & 4,4 & 2,79 \\
\hline & \multirow{4}{*}{90} & 70 & 2 & 2,36 \\
\hline & & 80 & 4,4 & 2,71 \\
\hline & & 90 & 4,2 & 3,72 \\
\hline & & 100 & 3,2 & 4,03 \\
\hline \multirow{8}{*}{1,5} & \multirow{4}{*}{80} & 70 & 2 & 2,98 \\
\hline & & 80 & 5,1 & 3,40 \\
\hline & & 90 & 4,8 & 4,03 \\
\hline & & 100 & 3,8 & 4,34 \\
\hline & \multirow{4}{*}{90} & 70 & 5 & 3,10 \\
\hline & & 80 & 5,9 & 4,43 \\
\hline & & 90 & 5,7 & 4,15 \\
\hline & & 100 & 4,8 & 4,34 \\
\hline \multirow{8}{*}{2} & \multirow{4}{*}{80} & 70 & 2 & 3,44 \\
\hline & & 80 & 3,6 & 3,78 \\
\hline & & 90 & 2,4 & 4,22 \\
\hline & & 100 & 2 & 4,30 \\
\hline & \multirow{4}{*}{90} & 70 & 2 & 3,72 \\
\hline & & 80 & 5,4 & 4,02 \\
\hline & & 90 & 4,9 & 4,24 \\
\hline & & 100 & 3,7 & 4,31 \\
\hline
\end{tabular}




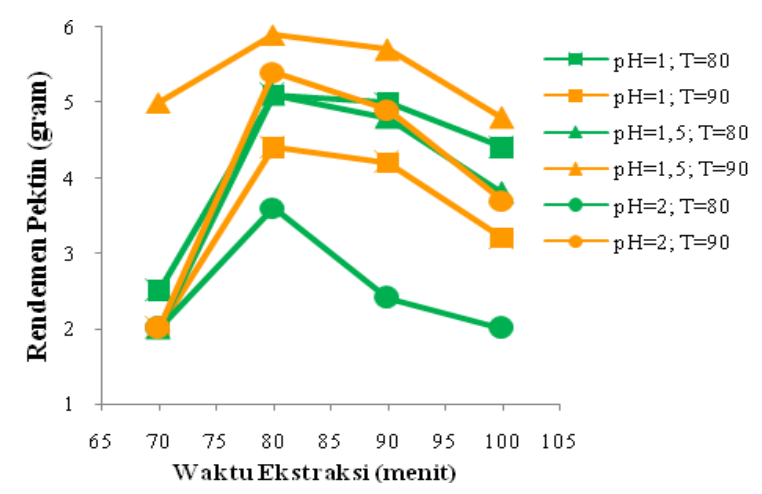

Gambar 4. Pengaruh pH dan waktu ekstraksi terhadap rendemen pectin

B. Pengaruh $\mathrm{pH}$ dan waktu ekstraksi terhadap kadar air pektin

Kadar air pektin yang dihasilkan semakin rendah dengan meningkatnya suhu dan semakin lamanya waktu ekstraksi. Kadar air yang tinggi disebabkan suhu yang rendah tidak mampu menguapkan air pada pektin, sebaliknya semakin tinggi suhu dan semakin lama waktu ekstraksi akan meningkatkan penguapan jumlah air selama proses ekstraksi sehingga mempermudah proses pengeringan [1].

Pektin yang dihasilkan pada penelitian ini berkisar antara 10,58-11,93\% yang sesuai dengan standar mutu kadar air pektin yang ditetapkan IPPA (International Pectin Producers Association), yaitu maksimum 12\%.

Hasil kadar air pisang raja tertinggi diperoleh sebesar $11,93 \%$ pada $\mathrm{pH} 1,5$ suhu $90{ }^{\circ} \mathrm{C}$ dan waktu ekstraksi 80 menit seperi yang terlihat pada gambar 5 .

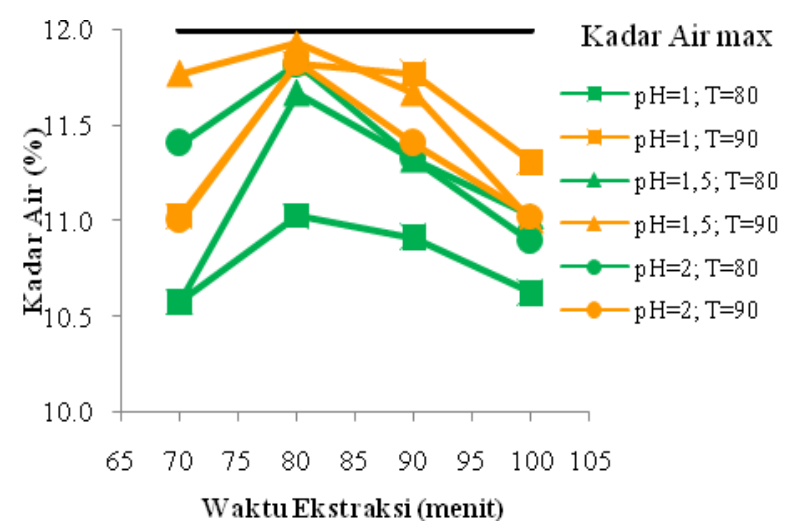

Gambar 5. Pengaruh pH dan waktu ekstraksi terhadap kadar air pektin

C. Pengaruh $\mathrm{pH}$ dan waktu ekstraksi terhadap kadar abu pektin

Pada gambar 6 menunjukkan tingginya suhu dan lamanya ekstraksi mengakibatkan kadar abu pektin semakin tinggi. Hal ini terjadi karena adanya reaksi hidrolisis protopektin. Hidrolisis protopektin menyebabkan bertambahnya kandungan kalsium dan magnesium. Kalsium dan magnesium merupakan mineral sebagai komponen abu. Dengan demikian semakin banyaknya mineral berupa kalsium dan magnesium akan semakin banyak kadar abu pektin tersebut [1].

Pada penelitian ini kadar abu yang diperoleh berkisar 0,79-9,45\% sehingga dapat diterima karena berdasarkan IPPA (International Pectin Producers Association), kadar abu maksimum pektin adalah $10 \%$. Tetapi kurang sesuai menurut Food Chemical Codex karena kadar abu pektin yang diijinkan kurang dari $1 \%$.

Hasil kadar abu pisang raja terbaik diperoleh sebesar $0,79 \%$ pada $\mathrm{pH} 1,5$ suhu $90{ }^{\circ} \mathrm{C}$ dan waktu ekstraksi 80 menit.

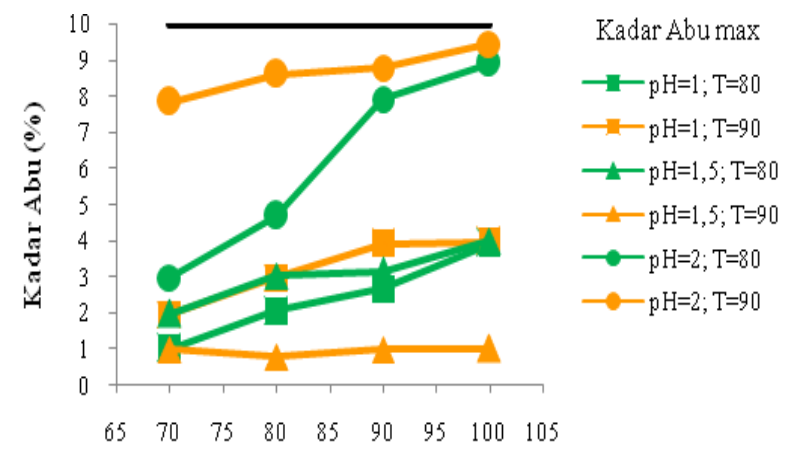

WaktuEkstraksi (menit)

\section{Gambar 6. Pengaruh pH dan waktu ekstraksi terhadap kadar abu pektin}

D. Pengaruh $\mathrm{pH}$ dan waktu ekstraksi terhadap berat ekivalen pektin

Suhu yang tinggi dan semakin lama ekstraksi menyebabkan terjadinya depolimerisasi dan demetilasi. Selain itu suhu tinggi dapat menyebabkan pula proses deesterifikasi pektin menjadi asam pektat. Proses deesterifikasi akan meningkatkan jumlah gugus asam bebas. Peningkatan jumlah gugus asam bebas akan menurunkan berat ekivalen [21].

Pada penelitian ini berat ekivalen yang diperoleh dapat diterima seperti yang terlihat pada gambar 7, karena berdasarkan standar IPPA (International Pectin Producers Association) berat ekivalen adalah 600-800 mg. 


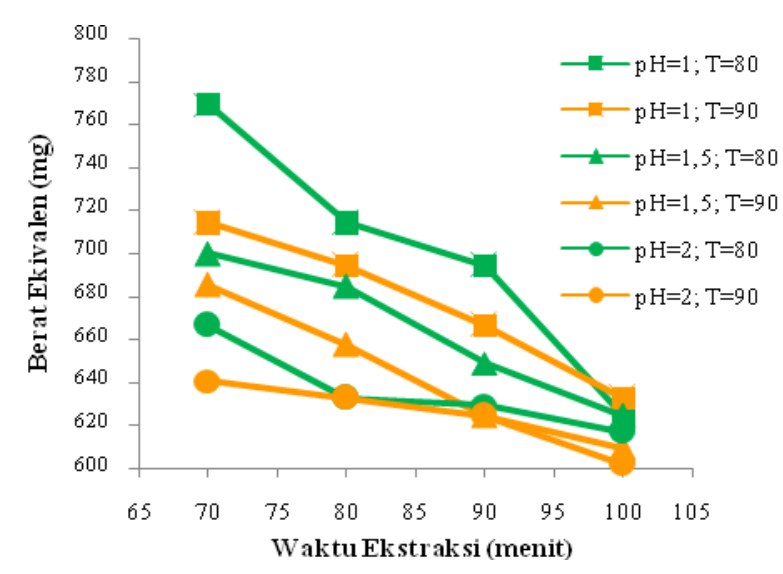

Gambar 7. Pengaruh pH dan waktu ekstraksi terhadap berat ekivalen pektin

E. Pengaruh $\mathrm{pH}$ dan waktu ekstraksi terhadap kadar metoksil pektin

Menurut Constenla dan Lozano (2003), kadar metoksil pektin akan semakin tinggi dengan meningkatnya suhu. Gambar di atas menunjukkan bahwa kadar metoksil pektin semakin tinggi dengan meningkatnya suhu dan semakin lamanya waktu ekstraksi. Hal ini dapat disebabkan gugus karboksil bebas yang teresterifikasi semakin meningkat.

Berdasarkan data range kadar metoksil terendahtertinggi, dapat dinyatakan bahwa pektin kulit buah pisang raja termasuk golongan pektin yang mempunyai kadar metoksil rendah. Hal tersebut merujuk pada ketentuan IPPA (International Pectin Producers Association) yang menggolongkan pektin dengan kadar metoksil 2,5\%-7,12\% sebagai pektin berkadar metoksil rendah. Kadar metoksil pada penelitian ini telah sesuai dengan teori yang menyatakan kadar metoksil semakin tinggi seiring dengan meningkatnya waktu ekstraksi.

Hasil kadar metoksil tertinggi diperoleh sebesar $4,43 \%$ pada pH 1,5 suhu $90{ }^{\circ} \mathrm{C}$ dan waktu ekstraksi 80 menit seperti yang terlihat pada gambar 8 .

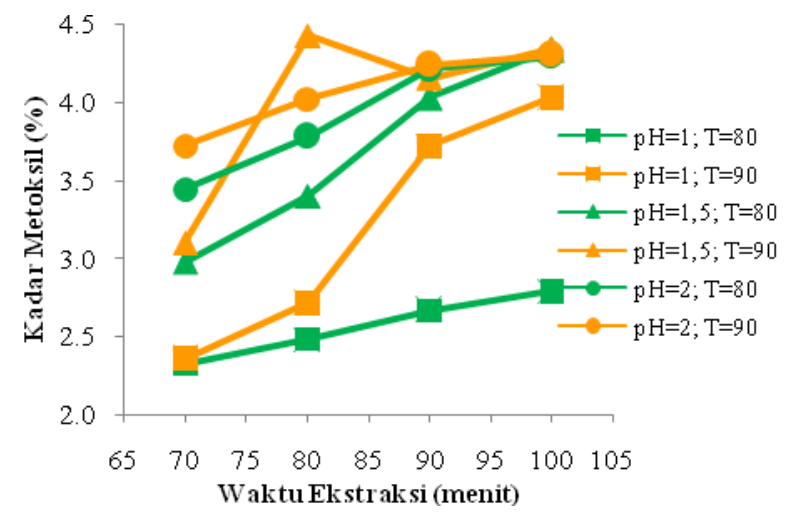

Gambar 8. Pengaruh pH dan waktu ekstraksi terhadap kadar metoksil pektin

\section{Kesimpulan}

1. Rendemen kulit pisang raja yang terbaik pada waktu ekstraksi 80 menit pada suhu $90{ }^{\circ} \mathrm{C}$ dan $\mathrm{pH}$ 1,5 yaitu $59 \%$.

2. Kadar air kulit pisang raja tertinggi diperoleh sebesar $11,93 \%$ pada $\mathrm{pH} 1,5$ suhu $90{ }^{\circ} \mathrm{C}$ dan waktu ekstraksi 80 menit.

3. Kadar abu kulit pisang raja terbaik diperoleh sebesar $0,79 \%$ pada $\mathrm{pH} 1,5$ suhu $90{ }^{\circ} \mathrm{C}$ dan waktu ekstraksi 80 menit.

4. Berat ekivalen kulit pisang raja yang diperoleh berkisar 600-800 mg.

5. Kadar metoksil tertinggi kulit piasng raja diperoleh sebesar $4,43 \%$ pada pH 1,5 suhu $90{ }^{\circ} \mathrm{C}$ dan waktu ekstraksi 80 menit.

\section{Daftar Pustaka}

[1] A. Budiyanto dan Yulianingsih, Pengaruh Suhu dan Waktu Ekstraksi terhadap Karakter Pektin dari Ampas Jeruk Siam (Citrus nobilis L), Jurnal Penelitian Pascapanen Pertanian 5(2), 2008.

[2] E. S., Guichard, A, Issanchou., Descovieres and P. Etievant., Pectin concentrat ion, molekular weight and degree of esterification, Influence on volatile composition and sensory caracteristic of strawberry jam, J. Food Science 56:1621, 1991.

[3] F.M Goycoolea,. and Adriana Cardenas, Pectins from Opuntia Spp. : A Short Review. J. PACD 17-29, 2003.

[4] G. Tchobanoglous, H. Theisen, dan S. Vigil, Integrated Solid Waste Management: Engineering Principles and Management Issues, New York: McGraw-Hill. Hal 3-22, 2003.

[5] Hasbullah, Teknologi Tepat Guna Agroindustri Kecil Sumatera Barat - Pektin Jeruk. Jakarta: Dewan Ilmu Pengetahuan, Teknologi dan Industri Sumatera Barat, 2001.

[6] H. Hart, L. E. Craine, dan D. J. Hart, Kimia Organik. Edisi Kesebelas, Jakarta: Penerbit Erlangga, Hal 511, 2003.

[7] H. Yamada,. Kiyohara, H. and Matsumoto, T, Recent Studies on Possible Funct ion of Bioact ive Pektins and Pectic Polysaccharides from Medica, 2003.

[8] I. Kacem, H. Majdoub and S. Roudesli, Physicochemical properties of pectin from retama raetam obtained using sequential extraction, Journal of Applied Sciences 8(9) :1713- 1719, 2008. 
[9] International Pectin Producers Association, Pectin Commercial Production, http://www.google.com/IPPA.info.html, Diakses: 18 Pebruari 2012, 2003.

[10] I. Sofia, Produksi Pektinase dari Kulit Pisang dengan Jamur Aspergillus Niger, Jurusan Teknik Kimia, Institut Teknologi Bandung, 2008.

[11] JBS. Braverman, Citrus Product di dalam Handayani, 1987, Ekstraksi Pektin dari kulit Buah Jeruk Besar (Citrus grandis Osbek), Skripsi, FATETA, IPB, Bogor, Hal 37-44, 1949.

[12] K.C Chang,. and A. Miyamoto, Gelling characteristics ofpektin from sunflower head residue, Dalam Sahari. M. A., A. Akbarian and M. Hamedi, 2002, Effect of variety and acid washing method on extraction yield and quality of sunflower head pectin, J. Food Chemistry 83: 4347, 1992.

[13] K. Sirotek, L. Slovakova, J. Kopecny and M. Marounek, Fermentation of pectin and glucose, and activity of pectindegrading enzymes in the rabbit caecal bacterium Bacteroides caccae, Letters in Applied Microbiology 38: 327-332, 2004.

[14] L. H. Meyer, Food Chemistry, AVI Publishing, Co. Westport, Connecticut, 1978.

[15] Medan Bisnis, Produksi Pisang Barangan. http://www.medanbisnisdaily.com, Diakses: 26 Pebruari 2012.

[16] M. H. Canteri-Schemin,., H.R. Fertonani, N. Waszczyaskyj and G. Wosiacki, Extraction of Pektin from Apple. Brazilian Archives of Biology and Technology, Vol. 48 n.2: pp. 259-266, 2005.

[17] M. Khotimchenko, Kovalev, V. and Y. Khotimchenko, Equilibrium studies of sorption of lead (II) ions by different pectin compounds, Journal of Hazardous Materials 149 (3): 693-699, 2007.

[18] S. Hoejgaard, Pectin Chemistry, Funcionality and Applications, http://www.cpkelco. com /Ptalk/ ptalk.htm, Tanggal akses 10 Mei 2006, 2004.

[19] S. Yeoh, J. Shi, dan T. Langrish, Comparison Between Different Techniques for Water Based Extraction of Pectins from Orange Peels, Desalination, 218, Hal 229-237, 2008.

[20] W. G. T. Willat, J. Paul Knox and J.D. Mikkelsen, Pectin : new insights into on old polymer are starting to gel, Trends in Food Science and Technology 17: 97-1004, 2006.

[21] W.J Kim, C.J.B. Smit and V.N.M. Rao, Demethylation ofpectin using acid and ammonia, J. Food Science 43, 74-78, 1978. 